\title{
Evaluating competing theories of street entrepreneurship: some lessons from a study of street vendors in Bangalore, India
}

\author{
Colin C. Williams • Anjula Gurtoo
}

Published online: 22 August 2012

(C) Springer Science+Business Media, LLC 2012

\begin{abstract}
Conventionally, street entrepreneurs were either seen as a residue from a premodern era that is gradually disappearing (modernisation theory), or an endeavour into which marginalised populations are driven out of necessity in the absence of alternative ways of securing a livelihood (structuralist theory). In recent years, however, participation in street entrepreneurship has been re-read either as a rational economic choice (neoliberal theory) or as conducted for cultural reasons (post-modern theory). The aim of this paper is to evaluate critically these competing explanations for participation in street entrepreneurship. To do this, face-to-face interviews were conducted with 871 street entrepreneurs in the Indian city of Bangalore during 2010 concerning their reasons for participation in street entrepreneurship. The finding is that no one explanation suffices. Some $12 \%$ explain their participation in street entrepreneurship as necessity-driven, $15 \%$ as traditional ancestral activity, $56 \%$ as a rational economic choice and $17 \%$ as pursued for social or lifestyle reasons. The outcome is a call to combine these previously rival explanations in order to develop a richer and more nuanced theorisation of the multifarious motives for street entrepreneurship in emerging market economies.
\end{abstract}

Keywords Street hawking - Street vendors · Entrepreneurship · Enterprise development $\cdot$ Informal economy $\cdot$ Economic development $\cdot$ Developing economies $\cdot$ India

\section{Introduction}

For many decades, the literature on entrepreneurship has been dominated by an idealtype depiction which represents the entrepreneur as an object of desire and

C. C. Williams $(\triangle)$

Management School, University of Sheffield, 358-360 Mushroom Lane, Sheffield S10 2TN, UK e-mail: c.c.williams@sheffield.ac.uk

A. Gurtoo

Department of Management, Indian Institute of Science, Bangalore, India 
entrepreneurship as a positive, wholesome and virtuous endeavour (Burns 2001; Cannon 1991). The outcome has been that entrepreneurs and forms of entrepreneurship which do not reinforce this ideal-type have been all too frequently ignored by, or excluded from, the mainstream entrepreneurship literature (Jones and Spicer 2009; Williams 2006). Recently, however, a small but burgeoning stream of literature has started to shine a spotlight on other (and 'othered') types of entrepreneur not reinforcing this ideal-type, such as informal sector entrepreneurs in western economies (De Soto 2001; Minard 2009; Small Business Council 2004; Venkatesh 2006; Volkov 2002; Webb et al. 2009; Williams 2006, 2009a, b, 2010, 2011; Williams and Round 2009; Williams and Nadin 2010, 2011, 2012; Williams et al. 2011, 2012) and street vendors in emerging market economies (Bhatt 2006; Bhowmik 2007; Charmes 1998; Cross 2000; Cross and Morales 2007; Das 2003; Gurtoo and Williams 2009; Unni and Rani 2003), both of which are anything but objects of desire.

So far, however, and despite this emergent interest in types of entrepreneur and entrepreneurship that challenge the ideal-type depiction, few have evaluated critically the competing explanations for participation in these other (and 'othered') types of entrepreneurship. The aim of this paper is to begin to fill that gap by evaluating the competing explanations for participation in street vending or hawking, or what is here termed 'street entrepreneurship'. To do this, a study will be reported of street entrepreneurs operating in the informal economy in the city of Bangalore in India.

To commence, therefore, the various possible reasons for engaging in street entrepreneurship in emerging market economies will be reviewed, ranging from its conventional depictions as either a residue from a pre-modern era that is disappearing (the modernisation perspective) or a necessity-driven survival practice (structuralist perspective), to its more contemporary depictions as a rational economic choice (neoliberal perspective) or as conducted for cultural reasons (post-structuralist perspective). To evaluate the relevance of these competing explanations, the methodology used to study the motives of street entrepreneurs in the Indian city of Bangalore will be outlined followed by the findings. Revealing that necessity-driven motives underpin the endeavour of just a small segment of street entrepreneurs in this Indian city, and that these different theorisations are applicable to varying segments of the population of street entrepreneurs and types of street entrepreneurship, the outcome in the concluding section will be the presentation of a finer-grained more nuanced theorisation that captures the multifarious nature of, and reasons for, street entrepreneurship in emerging market economies, along with a call for its wider validity to be tested in other contexts.

Before commencing, however, it is necessary to define what is here meant by street entrepreneurship. For adherents to the ideal-type depiction of entrepreneurs as objects of desire and entrepreneurship as positive, wholesome and virtuous, the type of entrepreneur and form of entrepreneurship (street vendors) studied in this paper might not be seen as entrepreneurs and entrepreneurship 'proper'. However, the standard definition of the entrepreneur used in Global Entrepreneurship Monitor (GEM) surveys, which defines an entrepreneur as somebody actively involved in starting a business or is the owner/manager of a business (Harding et al. 2006; Reynolds et al. 2002), clearly includes street entrepreneurs who after all start-up a business venture or own/manage a business. Such street entrepreneurs, who offer goods for sale to the public on the streets without having any permanent built structure from which to sell 
(Bhowmik 2007; Cross 2000), are either stationary, occupying space on the pavement or some other public/private space, or are mobile carrying their wares on push carts or in baskets on their heads.

Although street entrepreneurs do not by definition operate in the informal economy, and can in theory exist anywhere on a continuum from wholly formal at one end to wholly informal at the other, most in lived practice in emerging market economies inhabit a position somewhere towards the informal economy end of the spectrum, here defined using the standard International Labour Office definition as 'all economic activities by workers and economic units that are - in law or in practice - not covered or insufficiently covered by formal arrangements' (ILO 2002a, 2011; Hussmanns 2005). They usually lack appropriate business permits, violate zoning codes, fail to report tax liability, lack compliance with labour regulations governing work conditions, and/or lack legal guarantees in relation to suppliers and clients.

\section{Explaining street entrepreneurship: competing perspectives}

In recent years, considerable progress has been made in advancing the field of entrepreneurship and innovation (Alpkan et al. 2010; Andersén 2011; Cavalcante et al. 2011; Cambra-Fierro et al. 2011; Cantarello et al. 2011; Cegarra-Navarro et al. 2011; Chilton and Bloodgood 2010; Curado et al. 2011; Giaglis and Fouskas 2011; Gámez-González et al. 2010; Goktan and Miles 2011; Ho et al. 2011; Hotho and Champion 2011; Houthoofd et al. 2010; Huang et al. 2010; Huarng and Yu 2011; Kesting and Ulhøi 2010, Lin et al. 2010; Naranjo-Valencia et al. 2011; Rowley et al. 2011; Zhang and Duan 2010). This paper seeks to further extend this progress by addressing the subject of street entrepreneurship. When explaining street entrepreneurship in emerging market economies, a review of the literature reveals four competing theories, namely a long-standing modernisation perspective which holds that such endeavour is a pre-modern traditional activity, an increasingly dominant structuralist perspective that represents such activity as necessity-driven, an emergent neo-liberal perspective depicting such endeavour as a rational economic choice and a post-modern perspective portraying such activity as again voluntarily pursued but more by social actors for cultural reasons. Below, each is reviewed in turn.

\section{Modernisation perspective: a pre-modern traditional economic activity}

For most of the last century, it was widely assumed that street hawkers and peddlers were a residue or leftover from an earlier pre-modern era and their persistence taken as a signal of 'under-development', 'traditionalism' and 'backwardness'. The emergent modern formal economy, meanwhile, was seen to represent 'progress', 'development' and 'advancement' (Bairoch 1973; Geertz 1963; Gilbert 1998; Lewis 1959; Packard 2007). As Lyon (2007: 165) asserts, street vendors in this view are depicted as 'a residual labour category' which as Bromley (2007: Xv) summarises, is from this perspective viewed 'as unimportant and destined to disappear'.

Seen through this lens, therefore, the future is one of modern shopping centres, supermarkets and department stores. Street entrepreneurs are deemed parasitic or at 
best inefficient; part of a pre-modern traditional economic order that survives only at the fringes of modern society and is the antithesis of everything deemed modern. In this view, as Bromley (2007: $\mathrm{xv}$ ) summarises, street vending is 'a disorderly and superfluous activity that cluttered the urban environment, interrupted traffic flows, and competed unfairly with new, large, hygienic commercial establishments'. It is therefore something to be eradicated. A growing number of studies, however, refute this depiction of street entrepreneurship by revealing how street vending in the contemporary era remains an extensive phenomenon (Bhowmik 2007; Cross and Morales 2007).

Structuralist perspective: a necessity-driven activity

With this recognition of the widespread persistence and even growth of street entrepreneurship, a structuralist perspective has come to the fore which depicts this endeavour as a survival practice conducted out of economic necessity as a last resort in the absence of alternative means of livelihood. In this view, such entrepreneurship is a direct by-product of the advent of a de-regulated open world economy (Castells and Portes 1989; Gallin 2001; Portes and Haller 2004; Portes and Roberts 2005; Sassen 1997). From street-sellers in the Dominican Republic (e.g. Itzigsohn 2000), through Ghana (Lyons 2007) to street entrepreneurs in Somalia (Little 2003), the consensus is that this sphere is entered out of necessity as a survival strategy (e.g., Itzigsohn 2000).

These entrepreneurs are therefore depicted as unwilling and unfortunate pawns in an exploitative global economic system. As Bhowmik (2007: 96) states, for such marginalised populations, street vending 'is the only means for survival'. Indeed, jobs like cart vending, hawking, small store vendors, road side cobbling and pedal rickshaw driving are all commonly depicted by this structuralist perspective as necessity-driven endeavour which is highly insecure and unstable, composed of long hours, poor conditions, no legal or social protection, limited access to credit and very limited bargaining power (ILO 2002a, b; Kapoor 2007).

Neo-liberal perspective: a rational economic choice

For a group of neo-liberal commentators, however, street entrepreneurship is more a matter of choice than due to a lack of choice. For these neo-liberals, such entrepreneurs are heroes throwing off the shackles of a burdensome state and making a rational economic decision to enter street vending so as to escape over-regulation in the formal realm (Becker 2004; De Soto 1989, 2001; London and Hart 2004; Nwabuzor 2005; Small Business Council 2004). As Nwabuzor (2005: 126) asserts, 'Informality is a response to burdensome controls, and an attempt to circumvent them', or as Becker (2004: 10) puts it, 'informal work arrangements are a rational response by micro-entrepreneurs to over-regulation by government bureaucracies'. For De Soto (1989: 255) in consequence, 'the real problem is not so much informality as formality'.

Street entrepreneurship, therefore, is viewed as the people's 'spontaneous and creative response to the state's incapacity to satisfy the basic needs of the 
impoverished masses' (De Soto 1989: xiv-Xv). It is a rational economic strategy pursued by entrepreneurs whose spirit is stifled by state-imposed institutional constraints and who voluntarily operate in the informal economy to avoid the costs, time and effort of formal registration (Cross and Morales 2007; de Soto 1989, 2001; Perry and Maloney 2007; Small Business Council 2004).

Post-modern perspective: entrepreneurs as cultural/social actors

A final perspective again depicts such entrepreneurship as voluntarily chosen but rather than view it as a rational economic decision, it is seen more as a cultural endeavour. This is inspired by a small tributary of critical, postcolonial, post-structuralist, post-development and post-capitalist thought that moves beyond the conventional 'thin' portrayal of economic endeavour as always purely market-like and profit-motivated and instead adopts 'thicker' portrayals of the participation in economic endeavour which recognise the complex mix of logics, including social, community and cultural logics, often involved (Bourdieu 2001; Chakrabarty 2000; Escobar 1995; Gibson-Graham 2006; Leyshon et al. 2003).

This has resulted in street entrepreneurs being viewed more as social actors. Firstly, attention has been drawn to not only how the social relations between street entrepreneurs differ to normal market relations in that business and friendship relations blur and there is greater community solidarity and reciprocity, but also how exchange relations between street entrepreneurs and their customers differ to mainstream market relations in that without recourse to a legal contract, interpersonal relations and trust become more important (Cross and Morales 2007). Secondly, there has been a focus on how such entrepreneurship is pursued as a choice because of the greater personal freedom and flexibility it affords and allows them to gain control over their lives (e.g., Cross 2000; Hart 1973) and third and finally, how this endeavour is often in the eyes of participants an expression of community support which allows customers to source goods they otherwise could not afford (Cross 2000).

Evaluating the validity of the rival perspectives

Until now, these four theorisations have been largely viewed as mutually exclusive rival explanations. Most commentators depict such entrepreneurship as taking place according to a single unique 'logic' or at best, pay lip-service to other logics but contend that one particular explanation predominates (e.g., De Soto 2001; Snyder 2004). To evaluate these perspectives, therefore, this paper evaluates their validity by examining street entrepreneurs in the emerging market economy of India. Until now, it has indeed been assumed that such endeavour is indeed necessity-driven (Bhatt 2006; Chen et al. 1999, 2004; Carr and Chen 2004; Chant 2007; Charmes 1998; Fawzi 2003; ILO 2006). This, however, is an a priori assumption rather than an evidence-based finding. Here, therefore, the intention is to evaluate critically whether this is indeed the case by evaluating the validity of these four contrasting theorisations by studying the motives of street entrepreneurs in the Indian city of Bangalore. 


\section{Examining street entrepreneurs in Bangalore, India}

Situating the study: Bangalore, India

The Government of India (2004) estimates that there are some 10 million street vendors in the country. Until now, three major studies have been conducted of street hawkers in India (Bhowmik 2007; Sharma 1998; SNDT Women's University-ILO 2001). These studies reveal how earnings range between Rs50 to Rs80 per day (Rs50 = US\$1), or US\$1.00-1.59 per day (Bhowmik 2000, 2007; Sharma 1998; SNDT Women's University-ILO 2001). Given that some $20 \%$ of their earnings are taken as bribes or rents by municipal authorities or intermediaries (Bhowmik 2000), average earnings are between US\$0.80-1.27 per day after bribes and/or rents.

Bangalore, the fifth largest city in India with a population of 5.8 million, has about 30,000 street vendors, which is less than in similar sized cities such as Mumbai and Calcutta, possibly because alternative employment opportunities are more readily available in Bangalore (Bhowmik 2007). Street vending in the city centre is undertaken mostly by permanent vendors located near the main markets. In the suburbs, meanwhile, mobile vendors are more prevalent with their goods carried in baskets on their heads or on carts.

Street hawking in Bangalore is regulated by a number of acts of the Karnataka state government. The, 1964 Karnataka Municipalities Act obliges municipal councils to make adequate provision for vegetable vending. A 1966 Karnataka Municipalities by-law makes special provision that in certain streets and roads, specified by the municipal councils, the sale of vegetables, fruits, etc. may be permitted temporarily and that a monthly or daily fee may be charged. In 2000, as a result of a High Court judgment, the Bangalore Mahanagarpalike (the municipal corporation) issued a draft notification stating that hawking can be carried on only in specified hawking zones and only between 8.00 am and $8.00 \mathrm{pm}$. Only one hawking license is issued per family at a fee of Rs. 150 (US\$3) per month payable in advance, amounting to Rs3600 (US\$72). The license may be renewed at the discretion of the commissioner. Given that most hawkers earn between Rs50 to Rs80 per day (Rs50 = US\$1), or around Rs1500-2,400 per month (US\$30-48), this license amounts to 10-16\% of their earnings (Bhowmik 2000).

Until now, it has been simply assumed that these street entrepreneurs are necessitydriven. In 2010, therefore, the decision was taken to undertake a survey to evaluate their reasons for participating in street entrepreneurship.

Methodology for studying street entrepreneurship in Bangalore

Having been awarded a US $\$ 1,000$ best paper prize at the International Council of Small Business (ICSB) 2010 World Conference, the authors of this paper decided to use this award to conduct an empirical study of the reasons for street hawking in Bangalore. To conduct the interviews, two research assistants were employed along with 11 young adults, seven of whom were children of street vendors. All attended the Friends of Children Trust school, which is a charitable organisation that provides support to under-privileged children wishing to enter higher education (http:// 
www.friendsofchildrentrust.org). The money was used to provide training in both interviewing as well as data collation.

The benefits of using children of street vendors as interviewers were that: it enabled a relationship of trust between the interviewer and interviewee to be quickly established; the interviewers had a sensitive appreciation of the complexities of the subject matter under investigation; they spoke the local dialect of 'Kannada' widely used by the street vendors and perhaps most importantly, they provided invaluable help in the design of the interview schedule. One potential disadvantage, it might be asserted, is that they would want to paint a more positive picture of street vendors than might otherwise be the case. However, examining the results of the interviews, no such discernible differences were identified when the interview results conducted by the seven who were children of street vendors were compared with the other four interviewers.

Following an initial pilot study in March 2010, 871 face-to-face interviews were conducted with street entrepreneurs in Bangalore between April and September 2010. If Bhowmik (2007) is correct that Bangalore has around 30,000 street vendors, then this survey interviewed some $3 \%$ of all street entrepreneurs in this city. To choose street entrepreneurs for interview, maximum variation sampling was used to select three varying neighbourhood-types, namely commercial, residential and industrial districts and following this, one relatively affluent and one relatively deprived commercial, residential and industrial district was selected.

As Table 1 displays, Gandhi Nagar and Commercial Street were selected as contrasting commercial areas, each with a starkly contrasting customer base for the street entrepreneurs. Meanwhile, Gandhi Bazaar and Madiwaala were selected as contrasting residential areas where the vendors are mainly women here with baskets or pushcarts and the peak hours of vending are during the morning or evening strolls of the residents. Peenya $2^{\text {nd }}$ stage, Koramangala and Malleshwaram were selected as contrasting industrial districts since each has a very different customer base for the street entrepreneurs who mainly operate from mobile pushcarts. Peenya is a manufacturing hub, Koramangala has a large number of IT and consultancy companies, and Malleshwaram is a mix of commercial and residential units.

Table 1 Locations surveyed in Bangalore

\begin{tabular}{lcc}
\hline District surveyed & $\begin{array}{l}\text { Number of street } \\
\text { entrepreneurs } \\
\text { surveyed }\end{array}$ & $\begin{array}{l}\text { Length of street } \\
\text { surveyed }\end{array}$ \\
\hline Commercial area: & 247 & 700 \\
Gandhi Nagar & 129 & \\
Commercial street & 118 & $800 \mathrm{~m}$ \\
Residential area & 302 & $1,500 \mathrm{~m}$ \\
Gandhi Bazaar & 144 & \\
Madiwaala & 158 & \\
Industrial area: & 322 & \\
Peenya 2 & 106 & \\
Koramangala & 118 & \\
Malleshwaram & 98 & \\
\hline
\end{tabular}


Within these seven locations, a spatially stratified sample was used to select street entrepreneurs for interview. Given the definition of a street entrepreneur as somebody selling goods on the street without any permanent built structure from which to sell, only vendors operating out of a temporary (rough or wooden) structure, or from 'premises' with a roof made of cardboard, metal sheet or thick plastic, as well as mobile vendors, were sought for interview. Vendors in a permanent structure, with rent payable, were excluded from the sampling frame. Given that the roads on which these vendors were located ranged from $700 \mathrm{~m}$ to $1,500 \mathrm{~m}$, the decision was taken to interview street entrepreneurs at about 3-15 m intervals, depending on the district studied, in order to generate a spatially stratified sample along each road.

This sampling frame therefore generated data from heterogeneous types of street entrepreneur in a wide range of locations, who may possess very different rationales for participating in street vending. It prevented studying a narrow range of street vendors in one location who might all similarly explain their participation in this entrepreneurial endeavour. To collect the data, face-to-face interviews were conducted both during the mornings and evenings, as well as on weekdays, Saturdays and Sundays, over a period of 6 months during 2010.

A structured interview schedule was used. Firstly, this sought socio-demographic data on their age and gender, as well as how long they had been operating in this location along with why they had chosen it. The second section then sought data on the character of their street hawking, including the nature of their business, hours worked, whether they pay rent and how much, why they engage in street vending and whether they would prefer an office job or alternative means of livelihood if it was offered and why. The third section then sought information on their workplace, including whether they operated out of a fixed or mobile premises, why they had chosen that location, why they chose this endeavour, the problems involved in street entrepreneurship and why customers use them. All of the results reported below have been analysed with tests of statistical significance, namely Chi square tests with binomial value, using SPSS (Standard Package for Social Sciences) software. When differences are discussed, all are statistically significant within a $95 \%$ confidence interval. Below, therefore, the results are reported.

\section{Explaining street entrepreneurship in Bangalore}

Examining the characteristics of the 871 street entrepreneurs interviewed in Bangalore, Table 2 reveals that street entrepreneurship involves the sale of either perishable products such as vegetables and fruit, or non-perishable products such as clothes and electrical goods. It also displays that although such entrepreneurs are not confined to a particular demographic group, they are more concentrated in some sociodemographic groups than others (e.g., $69 \%$ are women). Neither is street entrepreneurship a temporary form of work; $94 \%$ had never worked in a salaried job and $51 \%$ had been in their current location for over 5 years. Nearly half (47\%) spend $14 \mathrm{~h}$ working each day and nearly all work every day of the week. The minimum time spent vending was $9-10 \mathrm{~h}$ per day when the time spent procuring the goods is taken into account. In most cases, they spent at least $12 \mathrm{~h}$ working each day. Some $74 \%$ operated from a fixed location and the remaining $26 \%$ are mobile street 
entrepreneurs. Most earn between Rs.35-100 per day (US\$0.70-2.00), with those selling non-perishable goods earning between Rs.65-100 per day (US\$1.30-2.00) and those selling perishable goods between Rs.35-50 per day (US\$0.70-1.00). Many took loans from moneylenders to pay for their license and the daily interest on these loans amounted to Rs.10 (10-29\% of their daily earnings). No vendor earned more than Rs3000 (US\$60) per month.

These street entrepreneurs, especially those with fixed stalls, frequently face harassment from the police and municipal authorities, although those operating in the suburbs and/or on a mobile basis are less harassed. Harassment takes the form of eviction and the fines range from Rs.50-100. To avoid eviction, Rs.2-3 is paid every day to the beat constable and half of street entrepreneurs pay such bribes at an average rate of $15 \%$ of their earnings. Assuming their earnings are US $\$ 1.25$ per day, this totals some US\$1 million per annum amongst the 30,000 street vendors in Bangalore. Indeed, of the half not paying such bribes and/or rents, two-thirds had deliberately chosen a location to avoid this 'tax' on their earnings.

\section{Reasons for participation in street entrepreneurship}

Turning to why they engage in street entrepreneurship, until now, the common assumption has been that they are driven out of economic necessity into this endeavour in the absence of other means of livelihood (Bhatt 2006; Bhowmik 2000, 2007; Fawzi 2003; ILO 2006; Morris 2011; Polese and Rodgers 2011). To evaluate the validity of this structuralist perspective, participants were asked in an open-ended manner, 'why did you choose street vending as a job?'. A question was then asked based on their first answer of the variety 'Is $x$ the only reason?' and finally, 'are there any other reasons?'. Their responses were then classified, in the manner shown in Table 3, according to whether they conform largely to the explanations proposed in the modernisation, structuralist, neo-liberal or post-structuralist accounts.

Just $12 \%$ of participants viewed themselves as being driven out of economic necessity into street entrepreneurship in the absence of other means of livelihood. If economic necessity is not their reason, then why do they engage in such entrepreneurial endeavour? Although in recent decades it has become to refute the modernisation thesis which depicts street entrepreneurship as a traditional pre-modern activity, this survey shows that for $15 \%$ of participants, this endeavour was conceived in terms of traditionalism, viewed as a traditional and/or ancestral way of working handed down to them across generations which they are continuing to pursue despite the encroachment of the modern formal economy.

For most street entrepreneurs, however, engagement in this endeavour is seen as a matter of choice, rather than due to a lack of choice. Some $56 \%$ explain their participation in street entrepreneurship in neo-liberal terms as a rational economic decision. They view such entrepreneurial endeavour as the best option open to them for making money because it pays more than alternative livelihoods, it is easy to establish themselves, requires low investment and expertise and there is a lack of competition from larger businesses. These street entrepreneurs, therefore, represent themselves as rational economic actors voluntarily engaging in street entrepreneurship. However, despite viewing themselves as voluntarily engaged in such entrepreneurship, most have a limited vision of the alternatives open to them. For the majority 
Table 2 Characteristics of street entrepreneurs, Bangalore, 2010

\section{Characteristic}

Age:

$\begin{array}{lr}18-30 \text { years } & 29 \\ 31-45 & 45 \\ 45-60 & 23 \\ 60 & 3\end{array}$

Gender:

Man

Woman

Employment history:

Ever worked in salaried job

9

Never worked in salaried job

91

Main business:

Vegetables or fruits 38

Flowers

20

Cigars, gutka or paan

2

Beverages or dairy products

Cooked meals, chats, etc.

Meat/fish

Handicrafts/pottery

Clothing/wool

Plants/seeds

Electronic gadgets

5

Length of time in business in this location:

$\begin{array}{ll}<1 \text { year } & 10 \\ 1-5 \text { years } & 39 \\ >5 \text { years } & 51\end{array}$

Length of working day:

Mornings (6.00-14.00)

Afternoon \& evenings

(14.00-20.00)

Full day (14 h)

Type of business:

Mobile vendor

26

Fixed location stall

74

Range of earnings per day:

Rs.35-100 (US\$0.70-2.00)

Vendors of perishable goods

Rs.35-50 (US\$0.70-1.00)

Vendors of non-perishable goods

Interest on loans to pay for

Rs.65-100 (US\$1.30-2.00) license as $\%$ of daily earnings

Average \% of earnings on bribes to prevent eviction
10-29

15 
Table 3 Main reason for working as a street entrepreneur

\begin{tabular}{|c|c|c|c|}
\hline Examples of reasons & Type of reason & $\begin{array}{l}\text { Theoretical } \\
\text { explanation }\end{array}$ & $\begin{array}{l}\% \text { of all street } \\
\text { entrepreneurs } \\
\text { surveyed }\end{array}$ \\
\hline
\end{tabular}

Family tradition

Traditionalism

Modernization

15

Handed-down from ancestors

No other choice

Last resort

Economic
necessity/survival

Economic
necessity/survival

Economic necessity

No formal job opportunities

Forced off land

Option chosen for making money

Best way of making money

Rational economic Neo-liberalism
decision

56

Easy to set up

Money/income is more than any other job

Lack of competition from larger businesses

Limited expertise required

Low investment

Problems of over-regulation in formal economy

Problem of bribes in formal economy

Want flexibility

Lifestyle/social reasons Post-structuralism

17

Community feeling

Community support

of street entrepreneurs when considering whether they would prefer waged work, they envisage working as a maid or pion rather than in an office job in the formal sector. These street vendors, therefore, are comparing street vending with working as a maid or pion, which they view as highly exploitative work. Very few viewing street entrepreneurship as their choice, however, have ever held a salaried job (1\%).

A further $17 \%$ again view street entrepreneurship as a choice but adopt a postmodern perspective, viewing themselves more as social, community and cultural actors due to the flexibility they can achieve in their working lives, the community solidarity and support they witness and the self-identity that results from their participation in such activity. In western terms, these street hawkers might be viewed as 'lifestyle entrepreneurs' doing so due to the meaning and identity they find in such endeavour and community solidarity that results from their participation. Indeed, street entrepreneurship for this group is not so much about engaging in market-like transactions for profitmotivated purposes and more about community solidarity, identity and flexibility. These street entrepreneurs are more likely to have previously held a salaried job (26\% of them) but voluntarily choose street selling as their means of livelihood. Just $16 \%$ would stop street selling if a salaried 'office' job was offered to them.

Given this more nuanced differentiation of street entrepreneurs into four broad types ('traditionalists', 'survivalists', 'rational economic actors' and 'social actors') 
which reflect their reasons for engaging in such endeavour, attention here turns towards identifying the characteristics of each group in terms of their age, gender, location and nature of their businesses. Table 4 reveals some stark variations across these different segments of the population of street entrepreneurs.

Starting with 'traditionalist street entrepreneurs who are carrying forward the ancestral family line of work, their ventures tend to be fixed stalls located on the fringes of established markets and/or in established informal hawking zones both in lower- and higher-income areas of the city, where they are more likely to trade in perishable goods (e.g., vegetables, fruit, flowers, dairy products). They tend to work slightly fewer hours than other groups of street seller. Very few have ever worked in salaried employment or would be willing to shift to a salaried job if it were offered to them.

Table 4 Characteristics of street entrepreneurs: by rationale for participating in street entrepreneurship

\begin{tabular}{|c|c|c|c|c|}
\hline Characteristic & $\begin{array}{l}\text { Traditionalist } \\
\text { rationales }\end{array}$ & $\begin{array}{l}\text { Survivalist } \\
\text { rationales }\end{array}$ & $\begin{array}{l}\text { Rational economic } \\
\text { actor rationales }\end{array}$ & $\begin{array}{l}\text { Social actor } \\
\text { rationales }\end{array}$ \\
\hline Mean age & 34 & 34 & 37 & 33 \\
\hline \multicolumn{5}{|l|}{ Gender: } \\
\hline Men & 29 & 29 & 27 & 32 \\
\hline Women & 71 & 71 & 73 & 68 \\
\hline$\%$ previously in salaried job & 7 & 11 & 10 & 26 \\
\hline$\%$ would take salaried job if offered & 16 & 73 & 6 & 4 \\
\hline \multicolumn{5}{|l|}{ Location } \\
\hline Higher-income district & 52 & 24 & 48 & 80 \\
\hline Lower-income district & 48 & 76 & 52 & 20 \\
\hline \multicolumn{5}{|l|}{ Length of working day } \\
\hline Mornings (6 h) & 32 & 22 & 25 & 40 \\
\hline Afternoon $\&$ evenings $(8 \mathrm{~h})$ & 29 & 21 & 25 & 46 \\
\hline Full day $(>14$ h) & 39 & 57 & 50 & 14 \\
\hline \multicolumn{5}{|l|}{ Type of business: } \\
\hline Mobile vendor & 15 & 54 & 20 & 22 \\
\hline Permanent stall & 85 & 46 & 80 & 78 \\
\hline \multicolumn{5}{|l|}{ Main business: } \\
\hline Vegetables or fruits & 41 & 42 & 36 & 34 \\
\hline Flowers & 25 & 24 & 10 & 11 \\
\hline Cigars, gutka or paan & 4 & 1 & 0 & 0 \\
\hline Beverages or dairy products & 4 & 5 & 0 & 0 \\
\hline Cooked meals, chats, etc. & 15 & 13 & 8 & 8 \\
\hline Meat/fish & 3 & 2 & 0 & 0 \\
\hline Handicrafts/pottery & 0 & 0 & 2 & 3 \\
\hline Clothing/wool & 8 & 11 & 28 & 29 \\
\hline Plants/seeds & 0 & 1 & 4 & 5 \\
\hline Electronic gadgets & 0 & 1 & 10 & 10 \\
\hline
\end{tabular}


Analysing 'survivalist' street entrepreneurs driven by economic necessity into this realm, meanwhile, $11 \%$ have previously worked in salaried employment and in contrast to traditionalist street entrepreneurs, $73 \%$ would accept a salaried job if it were offered, reflecting how street entrepreneurship is their first option but not their first choice for a livelihood. Their ventures tend to be located in lower-income districts of the city and they tend to be largely mobile vendors rather than occupy fixed stalls, trading in perishable goods (e.g., vegetables, fruit, flowers, dairy products) and working long hours relative to traditionalist street entrepreneurs and those more voluntarily engaging in such endeavour.

Of the 'rational economic actor' street entrepreneurs, just $10 \%$ have previously held a salaried job and only $6 \%$ would shift to a salaried job if it were offered to them, reinforcing how this for them is a matter of choice, rather than due to a lack of choice. Located in both high- and lower-income districts of the city, with business ventures largely in the form of fixed stalls, they tend to be less likely to trade in perishable goods (e.g., vegetables, fruit, flowers, dairy products) and instead to trade in non-perishable goods (e.g., clothing, electronic gadgets, handicrafts) and to work longer hours than traditionalist street entrepreneurs.

Analysing 'social actor' (or 'lifestyle') street entrepreneurs, meanwhile, a large proportion $(26 \%)$ have previously held a salaried job but very few (4\%) would accept a salaried job if offered, reinforcing how for them street entrepreneurship is a matter of choice. They tend to be located in higherincome districts of the city and to have permanent rather than mobile stalls, from which they are more likely to trade in non-perishable goods (e.g., clothing, electronic gadgets, and handicrafts) and work shorter hours than any other group of street entrepreneur.

Given these contrasting characteristics of different segments of the street entrepreneur population, Table 5 reveals the different problems each group confronts and also whether they view themselves as in transition to formalisation or not. For traditionalist street entrepreneurs, the income earned is not generally seen as a problem but the long hours worked to generate sufficient transactions is a significant issue. Neither do they see their lack of social protection as a problem and do not witness much harassment. Indeed, $97 \%$ are pro-formalisation in that they would like to have a license to sell their products, in order to pay taxes and to tighten control of street vending. They are also supportive of joining a vendor association to give them a voice, mainly in order to take care of problems with government authorities, such as corrupt officials (cited by $50 \%$ ).

For survivalist street entrepreneurs, the low income is again not generally a problem. Instead, and akin to traditionalist street entrepreneurs, the problem is the long hours they need to work to generate sufficient transactions. Some $13 \%$ see lack of social protection as a problem but few again witness harassment. However, they are less pro-formalisation than traditionalist street entrepreneurs in that a smaller proportion of them wish to have a license. For those wanting a license, moreover, their rationale is to tighten control of the number of street vendors. Despite being less pro-formalisation, when they want an association to give them voice, they express a preference for a government association, with the benefits sought from such an association being dealing with government authorities (cited by $22 \%$ ). 
Table 5 Problems faced by street entrepreneurs: by reason for participating in street entrepreneurship

\begin{tabular}{lllll}
\hline Characteristic & $\begin{array}{l}\text { Traditionalist } \\
\text { rationales }\end{array}$ & $\begin{array}{l}\text { Survivalist } \\
\text { rationales }\end{array}$ & $\begin{array}{l}\text { Rational } \\
\text { economic } \\
\text { actor rationales }\end{array}$ & $\begin{array}{l}\text { Social actor } \\
\text { rationales }\end{array}$ \\
\hline
\end{tabular}

Problems faced:

Low income

Few transactions

Long hours

No social protection

Harassment from government authorities

15

39

38

6

Pay bribes to officials

Daily

Weekly

Monthly

$\%$ wanting government license to sell

Reason wanting license:

Generate revenue for government

Tighten control of street vendors

Can have direct link with government rather than other organizations

Group prefer to join:

Vendor association

Trade union

Cooperative

Government association

None required

Benefits want from belonging to an organization:

\begin{tabular}{|c|c|c|c|c|}
\hline $\begin{array}{l}\text { Take care of problems with government } \\
\text { authorities }\end{array}$ & 50 & 22 & 31 & 48 \\
\hline $\begin{array}{l}\text { Assign space and enforce respect among } \\
\text { members }\end{array}$ & 10 & 12 & 3 & 9 \\
\hline Provide legal service & 19 & 12 & 8 & 14 \\
\hline Offer private security & 10 & 10 & 3 & 10 \\
\hline Offer life insurance & 20 & 11 & 5 & 18 \\
\hline Offer health benefits & 15 & 10 & 4 & 14 \\
\hline
\end{tabular}

For those engaging in street entrepreneurship as a rational economic choice, the low income is not generally a problem. Instead, it is their lack of social protection and the difficulty in generating sufficient transactions. This group are more likely to have witnessed harassment from government authorities; some $39 \%$ of them. Their solution, however, is not to formalise; just $46 \%$ want a government license to sell their products. Instead, they believe it is corrupt government officials who are the major problem and a license is desire mainly to by-pass the gangs, supported by political parties, corrupt police officials or municipal government officials who 
request bribes on a daily basis from them. Unlike other groups of street entrepreneur, however, a half of this group do not wish to join an organisation to give them voice, not least because they see such an organisation as being yet another layer of government bureaucracy and corruption. Indeed, the major function that such an association should pursue in their eyes is to take care of the problems they face with government authorities.

For social actor or lifestyle street entrepreneurs, the low income is more of a problem than for other groups, mostly because they are unable to generate sufficient transactions. However, few witness harassment from government and are more proformalisation than traditionalists and survivalists; $98 \%$ would like a license to sell their products. Their major reason is to tighten control over the number of street vendors. They also want a local vendor association to join that could deal with government authorities.

\section{Typology of the multifarious nature of street entrepreneurs}

\begin{tabular}{|c|c|}
\hline \multicolumn{2}{|c|}{ More anti-formalization } \\
\hline STRUCTURALIST & NEO-LIBERAL \\
\hline $\begin{array}{l}\text { Examples: } \\
\text { - involuntary informal entrepreneurs } \\
\text { (e.g., migrants, mobile vendors) }\end{array}$ & $\begin{array}{l}\text { Examples: } \\
\text { - voluntary informal entrepreneurs (e.g., } \\
\text { selling unusual, non perishable goods) }\end{array}$ \\
\hline $\begin{array}{l}\text { Where likely to be found: } \\
\text { - Lower-income areas }\end{array}$ & $\begin{array}{l}\text { Where likely to be found: } \\
\text { - Higher- and lower-income districts }\end{array}$ \\
\hline$\leftarrow$ Economic & Voluntary $\rightarrow$ \\
\hline necessity & \\
\hline $\begin{array}{l}\text { Examples: } \\
\text { - traditional informal entrepreneurs } \\
\text { (e.g. as part of entrepreneurial } \\
\text { communities, carrying forward family } \\
\text { line of work) }\end{array}$ & $\begin{array}{l}\text { Examples: } \\
\text { - voluntary entrepreneurs (e.g., only } \\
\text { working in mornings or evenings, } \\
\text { selling unusual or non perishable goods) }\end{array}$ \\
\hline Where likely to be found: & $\begin{array}{l}\text { Where likely to be found: } \\
\text { - Higher-income districts }\end{array}$ \\
\hline
\end{tabular}

- Established markets

- Established informal hawking zones

MODERNISATION

POST-MODERN

More pro-formalisation

Fig. 1 Typology of the multifarious nature of street entrepreneurs 


\section{Conclusions}

This paper has evaluated critically the competing explanations for street entrepreneurship that variously represent this activity as a traditional ancestral endeavour (modernisation theory), a survival strategy for those marginalised from the circuits of the modern economy (structuralism), an endeavour voluntarily pursued as a rational economic decision (neo-liberalism) or an endeavour chosen by social actors for lifestyle reasons (post-modernism). To evaluate these competing theories, a 2010 survey involving face-to-face interviews with street entrepreneurs in Bangalore has been analysed.

The finding is that no single theorisation is universally applicable to all the 871 street entrepreneurs surveyed. Instead, and as Fig. 1 summarises, each theorisation is valid for different segments of the street entrepreneur workforce. As such, it is only by combining these different explanations that a more accurate and finer-grained understanding of this form of informal entrepreneurial endeavour in this Indian city can be achieved. Rather than depict these as competing theorisations of street entrepreneurship, therefore, the argument is that they should be combined in order to achieve a fuller understanding of the heterogeneous nature of such entrepreneurial endeavour and multifarious varieties of street entrepreneur.

Having shown the need for this more theoretically integrative approach towards street entrepreneurship through this study of street vendors in Bangalore, future research might now examine street entrepreneurship in other contexts so as to evaluate critically the validity of pursuing a similar more nuanced understanding. If this paper consequently helps engender such an integrative understanding of the heterogeneous reasons for participating in street entrepreneurship in other contexts, then it will have achieved one of its major objectives. If this then helps the wider entrepreneurship literature to begin transcending the ideal-type depiction of entrepreneurs as an object of desire and enables a better understanding to emerge of the lived practices of entrepreneurship in the contemporary world, then it will also have fulfilled its wider intentions.

\section{References}

Alpkan, L., Bulut, C., Gunday, G., Ulusoy, G., \& Kilic, K. (2010). Organizational support for intrapreneurship and its interaction with human capital to enhance innovative performance. Management Decision, 48(5), 732-755.

Andersén, J. (2011). Strategic resources and firm performance. Management Decision, 49(1), 87-98.

Bairoch, P. (1973). Urban unemployment in developing countries. Geneva: International Labour Office.

Becker, K. F. (2004). The informal economy. Stockholm: Swedish International Development Agency.

Bhatt, E. (2006). We are poor but so many: the story of self-employed women in India. Oxford: Oxford University Press.

Bhowmik, S. K. (2000). Hawkers in the urban informal sector: a study of street vendors in six cities. Bangalore: National Alliance of Street Vendors of India. Available at www.nasvi.org.

Bhowmik, S. K. (2007). Street vending in urban India: the struggle for recognition. In J. Cross \& A. Morales (Eds.), Street entrepreneurs: people, place and politics in local and global perspective (pp. 89-123). London: Routledge.

Bourdieu, P. (2001). The forms of capital. In N. Woolsey-Biggart (Ed.), Readings in Economic Sociology (pp. 49-72). Oxford: Blackwell. 
Bromley, G. (2007). Foreword. In J. Cross \& A. Morales (Eds.), Street entrepreneurs: people, place and politics in local and global perspective (pp. Xv-xvii). London: Routledge.

Burns, P. (2001). Entrepreneurship and Small Business. Basingstoke: Palgrave.

Cambra-Fierro, J., Florin, J., Perez, L., \& Whitelock, J. (2011). Inter-firm market orientation as antecedent of knowledge transfer, innovation and value creation in networks. Management Decision, 49(3), 444467.

Cannon, T. (1991). Enterprise: creation, development and growth. Oxford: Butterworth-Heinemann.

Cantarello, S., Nosella, A., Petroni, G., \& Venturini, K. (2011). External technology sourcing: evidence from design-driven innovation. Management Decision, 49(6), 962-983.

Carr, M., \& Chen, M. (2004). Globalization, Social Exclusion and Work With Special Reference to Informal Employment and Gender. Geneva: Working Paper No. 20, Policy Integration Department, International Labor Office.

Castells, M., \& Portes, A. (1989). World underneath: the origins, dynamics and effects of the informal economy. In A. Portes, M. Castells, \& L. A. Benton (Eds.), The Informal Economy: studies in advanced and less developing countries (pp. 19-42). Baltimore: John Hopkins University Press.

Cavalcante, S. A., Kesting, P., \& Ulhøi, J. P. (2011). Business model dynamics and innovation: (Re)establishing the missing linkages. Management Decision, 49(8), 1327-1342.

Cegarra-Navarro, J. G., Sanchez-Vidal, M. E., \& Cegarra-Leiva, D. (2011). Balancing exploration and exploitation of knowledge through an unlearning context: an empirical investigation in SMEs. Management Decision, 49(7), 1099-1119.

Chakrabarty, D. (2000). Provincializing Europe: postcolonial thought and historical difference. Princeton: Princeton University Press.

Chant, S. (2007). The informal sector and employment. In V. Desai \& R. Potter (Eds.), The Companion to Development Studies (pp. 142-159). London: Hodder-Arnold.

Charmes, J. (1998). Street Vendors in Africa: Data and Methods. New York: United Nations Statistical Division.

Chen, M., Sebstad, J., \& Connell, L. (1999). Counting the invisible workforce: the case of home-based workers. World Development, 27(30), 603-610.

Chen, M., Carr, M., \& Vanek, J. (2004). Mainstreaming Informal Employment and Gender in Poverty Reduction: a handbook for policymakers and other stakeholders. London: Commonwealth Secretariat.

Chilton, M. A., \& Bloodgood, J. M. (2010). Adaption-innovation theory and knowledge use in organizations. Management Decision, 48(8), 1159-1180.

Council, S. B. (2004). Small Business in the Informal Economy: making the transition to the formal economy. London: Small Business Council.

Cross, J. C. (2000). Street vendors, modernity and postmodernity: conflict and compromise in the global economy. International Journal of Sociology and Social Policy, 20(1), 29-51.

Cross, J., \& Morales, A. (2007). Introduction: locating street markets in the modern/postmodern world. In J. Cross \& A. Morales (Eds.), Street entrepreneurs: people, place and politics in local and global perspective (pp. 1-13). London: Routledge.

Curado, C., Henriques, L., \& Bontis, N. (2011). Intellectual capital disclosure payback. Management Decision, 49(7), 1080-1098.

Das, K. (2003). Income and employment in informal manufacturing: a case study. In R. Jhabvala, R. M. Sudarshan, \& J. Unni (Eds.), Informal Economy Centrestage: new structures of employment (pp. 62103). London: Sage.

De Soto, H. (1989). The Other Path: the economic answer to terrorism. London: Harper and Row.

De Soto, H. (2001). The Mystery of Capital: why capitalism triumphs in the West and fails everywhere else. London: Black Swan.

Escobar, A. (1995). Encountering Development: the making and unmaking of the third world. Princeton: Princeton University Press.

Fawzi, C. (2003). Gender, Poverty and Employment in the Arab Region. Geneva: Capacity-Building Program on Gender, Poverty and Employment Discussion Paper, International Labour Office.

Gallin, D. (2001). Propositions on trade unions and informal employment in time of globalization. Antipode, 19(4), 531-549.

Gámez-González, J., Rondan-Cataluña, F. J., Diez-de Castro, E. C., \& Navarro-Garcia, A. (2010). Toward an international code of franchising. Management Decision, 48(10), 1568-1595.

Geertz, C. (1963). Peddlers and Princes: social change and economic modernization in two Indonesian towns. Chicago: University of Chicago.

Giaglis, G. M., \& Fouskas, K. G. (2011). The impact of managerial perceptions on competitive response variety. Management Decision, 49(8), 1257-1275. 
Gibson-Graham, J.-K. (2006). Post-Capitalist Politics. Minneapolis: University of Minnesota Press.

Gilbert, A. (1998). The Latin American City. London: Latin American Bureau.

Goktan, A. B., \& Miles, G. (2011). Innovation speed and radicalness: are they inversely related? Management Decision, 49(4), 533-547.

Government of India (2004). National Policy for urban street vendors/hawkers. Ministry of Urban Employment and Poverty Alleviation. Available at www.meupa.nic.in (last accessed 15 ${ }^{\text {th }}$ July 2012).

Gurtoo, A., \& Williams, C. C. (2009). Entrepreneurship and the informal sector: some lessons from India. The International Journal of Entrepreneurship and Innovation, 10(1), 55-62.

Harding, R., Brooksbank, D., Hart, M., Jones-Evans, D., Levie, J., O’Reilly, J., et al. (2006). Global Entrepreneurship Monitor United Kingdom 2005. London: London Business School.

Hart, K. (1973). Informal income opportunities and urban employment in Ghana. The Journal of Modern African Studies, 11(1), 61-89.

Ho, Y. C., Fang, H. C., \& Lin, J. F. (2011). Technological and design capabilities: Is ambidexterity possible? Management Decision, 49(2), 208-225.

Hotho, S., \& Champion, K. (2011). Small businesses in the new creative industries: innovation as a people management challenge. Management Decision, 49(1), 29-54.

Houthoofd, N., Desmidt, S., \& González-Fidalgo, E. (2010). Analyzing firm performance heterogeneity: The relative effect of business domain. Management Decision, 48(6), 996-1009.

Huang, J. Y., Chou, T. C., \& Lee, G. G. (2010). Imitative innovation strategies: Understanding resource management of competent followers. Management Decision, 48(6), 952-975.

Huarng, K. H., \& Yu, T. H. K. (2011). Entrepreneurship, process innovation and value creation by a nonprofit SME. Management Decision, 49(2), 284-296.

Hussmanns, R. (2005). Measuring the informal economy: From employment in the informal sector to informal employment. Geneva: Working Paper No. 53, Policy Integration Department Bureau of Statistics International Labour Office.

ILO. (2002a). Decent work and the informal economy. Geneva: International Labor Office.

ILO. (2002b). Women and Men in the Informal Economy: a statistical picture. Geneva: International Labor Office.

ILO. (2006). Decent Work for Women and Men in the Informal Economy: Profile and Good Practices in Cambodia. Geneva: International Labor Office.

ILO. (2011). Statistical update on employment in the informal economy. Geneva: ILO Department of Statistics.

Itzigsohn, J. (2000). Developing Poverty: the state, labor market deregulation and the informal economy in Costa Rica and the Dominican Republic. Pennsylvania: Pennsylvania State University Press.

Jones, C., \& Spicer, A. (2009). Unmasking the entrepreneur. Cheltenham: Edward Elgar.

Kapoor, A. (2007). The SEWA way: shaping another future for informal labour. Futures, 39(5), 554-568.

Kesting, P., \& Ulhøi, J. P. (2010). Employee-driven innovation: extending the license to foster innovation. Management Decision, 48(1), 65-84.

Lewis, A. (1959). The Theory of Economic Growth. London: Allen and Unwin.

Leyshon, A., Lee, R., \& Williams, C. C. (Eds.). (2003). Alternative Economic Spaces. London: Sage.

Lin, E., Lin, T. M. Y., \& Lin, B. W. (2010). New high-tech venturing as process of resource accumulation. Management Decision, 48(8), 1230-1246.

Little, P. D. (2003). Somalia: economy without state. Bloomington: Indiana University Press.

London, T., \& Hart, S. L. (2004). Reinventing strategies for emerging markets: beyond the transnational model. Journal of International Business Studies, 35(3), 350-370.

Lyon, F. (2007). Institutional perspectives on understanding street retailer behaviour and networks. In J. Cross \& A. Morales (Eds.), Street entrepreneurs: people, place and politics in local and global perspective (pp. 164-179). London: Routledge.

Minard, S. C. L. (2009). Valuing entrepreneurship in the informal economy in Senegal. Social Enterprise Journal, 5(3), 186-209.

Morris, J. (2011). Socially embedded workers at the nexus of diverse work in Russia: an ethnography of blue-collar informalization. International Journal of Sociology and Social Policy, 31(11/ 12), 619-631.

Naranjo-Valencia, J. C., Jiménez-Jiménez, D., \& Sanz-Valle, R. (2011). Innovation or imitation? The role of organizational culture. Management Decision, 49(1), 55-72.

Nwabuzor, A. (2005). Corruption and development: new initiatives in economic openness and strengthened rule of law. Journal of Business Ethics, 59(1), 121-138.

Packard, T. (2007). Do workers in Chile choose informal employment? a dynamic analysis of sector choice. Washington, DC: World Bank Latin American and the Caribbean Region Social Projection Unit. 
Perry, G. E., \& Maloney, W. F. (2007). Overview: Informality - exit and exclusion. In G. E. Perry, W. F. Maloney, O. S. Arias, P. Fajnzylber, A. D. Mason, \& J. Saavedra-Chanduvi (Eds.), Informality: exit and exclusion (pp. 1-20). Washington DC: World Bank.

Polese, A., \& Rodgers, P. (2011). Surviving post-socialism: the role of informal economic practices. International Journal of Sociology and Social Policy, 31(11/12), 612-618.

Portes, A., \& Haller, W. (2004). La economía informal. Santiago: Seria Políticas Sociales 100. División de Desarrollo Social_CEPAL, United Nations.

Portes, A., \& Roberts, B. (2005). The free-market city: Latin American urbanization in the years of the neoliberal experiment. Studies in Comparative International Development, 40(1), 43-82.

Reynolds, P., Bygrave, W. D., Autio, E., \& Hay, M. (2002). Global Entrepreneurship Monitor: 2002 Executive Monitor. London: London Business School.

Rowley, J., Baregheh, A., \& Sambrook, S. (2011). Towards an innovation-type mapping tool. Management Decision, 49(1), 73-86.

Sassen, S. (1997). Informalisation in Advanced Market Economies. Geneva: Issues in Development Discussion Paper 20, ILO.

Sharma, R. N. (1998). Census of hawkers on Brihanmumbai municipal corporation land. Mumbai: Tata Institute of Social Sciences and Youth for Unity and Voluntary Action.

SNDT Women's University-ILO. (2001). Street vendors in Mumbai, unpublished report.

Snyder, K. A. (2004). Routes to the informal economy in New York's East village: crisis, economics and identity. Sociological Perspectives, 47(2), 215-240.

Unni, J., \& Rani, U. (2003). Employment and income in the informal economy: a micro-perspective. In R. Jhabvala, R. M. Sudarshan, \& J. Unni (Eds.), Informal Economy Centrestage: new structures of employment (pp. 39-61). London: Sage.

Venkatesh, S. A. (2006). Off the books: the underground economy of the urban poor. Cambridge: Harvard University Press.

Volkov, V. (2002). Violent Entrepreneurs: the use of force in the making of Russian capitalism. Ithaca: Cornell University Press.

Webb, J. W., Tihanyi, L., Ireland, R. D., \& Sirmon, D. G. (2009). You say illegal, I say legitimate: entrepreneurship in the informal economy. Academy of Management Review, 34(3), 492-510.

Williams, C. C. (2006). The Hidden Enterprise Culture: entrepreneurship in the underground economy. Cheltenham: Edward Elgar.

Williams, C. C. (2009a). Explaining participation in off-the-books entrepreneurship in Ukraine: a gendered evaluation. International Entrepreneurship and Management Journal, 5(4), 497-513.

Williams, C. C. (2009b). The motives of off-the-books entrepreneurs: necessity- or opportunity-driven? International Entrepreneurship and Management Journal, 5(2), 203-217.

Williams, C. C. (2010). Spatial variations in the hidden enterprise culture: some lessons from England. Entrepreneurship and Regional Development, 22(5), 403-423.

Williams, C. C. (2011). Entrepreneurship, the informal economy and rural communities. Journal of Enterprising Communities, 5(2), 145-157.

Williams, C. C., \& Nadin, S. (2010). The commonality and character of off-the-books entrepreneurship: a comparison of deprived and affluent urban neighbourhoods. Journal of Developmental Entrepreneurship, 15(3), 1-14.

Williams, C. C., \& Nadin, S. (2011). Theorising the hidden enterprise culture: the nature of entrepreneurship in the shadow economy. International Journal of Entrepreneurship and Small Business, 14(3), 334-338.

Williams, C. C., \& Nadin, S. (2012). Entrepreneurship in the informal economy: commercial or social entrepreneurs? International Entrepreneurship and Management Journal, 8(3), 309-324.

Williams, C. C., \& Round, J. (2009). Evaluating informal entrepreneurs' motives: some lessons from Moscow. International Journal of Entrepreneurial Behaviour and Research, 15(1), 94-107.

Williams, C. C., Nadin, S., \& Baric, M. (2011). Evaluating the participation of the self-employed in undeclared work: some evidence from a 27-nation European survey. International Entrepreneurship and Management Journal, 7(3), 341-356.

Williams, C. C., Nadin, S., \& Rodgers, P. (2012). Evaluating competing theories of informal entrepreneurship: some lessons from Ukraine. International Journal of Entrepreneurial Behaviour and Research, $18(5), 528-543$.

Zhang, J., \& Duan, Y. (2010). The impact of different types of market orientation on product innovation performance: evidence from Chinese manufacturers. Management Decision, 48(6), 849-867. 